\title{
17 電解酸性水の使用条件による性状変化
}

\section{1. 原水およひ織維製品への含水使用の性状に与える影響}

加見谷将人, 新 太喜治（岡山大病院中央手術部）

[目的]最近，病院をはじめとして診療の現場にお いて, 電解酸性水が様々な用途に使用され，その検討 結果の報告が散見される. しかし，その臨床効果につ いては期待される結果が必ずしも得られていないのが 現状で，その上消毒・殺菌効果と創傷治瘱効果などが 混同されているため,さらにその評洒を難しくしてい るように思われる。また，電解酸性水の生成にあたっ ては，厳格な統一規格はなく，生成される水について あ同様にはっきりした規格がないが，同一機種におい てる使用する原水によって性状が㺺なり，これによっ ても臨床効果が異なってくる可能性が示唆される. 今 回我々は，使用する原水と生成される電解酸性水の性 状との関連,ならびにこの電解酸性水に䋐維製品を漫 漬させ，さらには吸収された電解酸性水を絞り出した 場合（絨維製品を用いて電解酸性水を使用する場合を 想定して）の電解酸性水の珄状の変化について検討し
たので報告する。

[万法] 異なった地域に执いて水道水を原水として 電解酸性水を生成しその性状を，pH・ORP（酸化社 元電位）・嘷素濃度等について検討した。 レーヨン・ポリェステル等の素材で作られたガーゼ・ モッブ等の㵶維製品について，それらを電解酸性水に 没漬した場合の織維製品の周䁳の，及び絞り出された 電解陵性水の性状について検预を行った。

[結果](1)電解酸性水の性状は原水によって異な

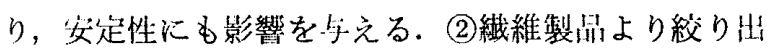
された電解酸性水はその性状が著しく劣化し，最後に 皎り出されたものほどとの程度は嘴しい。

[考察]電解酸性水を使用する場合，ての性状を子 め確諗するとともに，使用方法にも充分考虑する必留 が泫る。

\section{8 電解酸化水による消毒効果の検討}

片井敦雄, 田中智之, 田中米子, 永井 勲（社会保険紀南綜合病院）

[目的]アクアチッド NDX-250 KH 機器を用い $\tau, 10 \%$ 食塩添加水道水から, 電気分解によって得 られた電解酸化水（酸化水）の，消丵効果を検討した ので報告する.

[方法] 1）基礎的検討：ATCC 由来のS. aureus, E. coli, $P$. aeruginosa の 3 菌種々臨床由来株 MR SA, P. aeruginosa の 2 菌種合計 5 株を用いた。こ れらの满製菌液を, 原液酸化水・希採酸化水・水道水 の各々 $1 \mathrm{ml}$ に $10 \mu 1$ つつ加之, 15秒間室温放固後 その $0.1 \mathrm{ml}$ を血液寒天培地に接種し，殺菌効果を見 た. 2）手指手洗いの消毒効果：通過性細菌を，30名

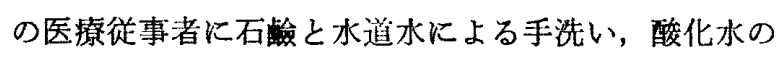
流水15秒間の手洗い雨方での比較を行い，何れるバムスタンブ法で細菌分離を行った，手指の常在細菌凿 の殺菌效果は，16名の看護学生によりグローブジュー ス法で害施し，血淮寒天培地にて定量培善し減菌率で 評俩した３）林清拭の消毒効果：酸化水にモップを 10分間浸した後, 新しい酸化水で清拭し，その前後の
休のサンプリングを行った、同時に使用した酸化水る 検查に供した.

[結果] 1) 基礎的検討では，酸化水（ph 2.7, 残留塩素 $35 \mathrm{ppm}$, 酸化還元電位 $1100 \mathrm{mv}$ ) の50倍者 秎まで， 5 菌株全てに殺菌効果が認められた。水道水 では E. coli に殺菌が見られたのみであった，2）通 過胜細菌の手洗い効果は, 手沙い後菌数が前菌数の 90\% 以上の減菌が見られたのは 12/17(70.5\%)で， 石踰手洗いの 9/20 (45\%) に比べて有効であった. 手指常在細菌丵の, 減菌染では, 減菌率 $58.2 \%$ から $99.8 \%$, 平均 $88 \%$ にみられやや良好であった。酸化 水による休の清拭消淁效果は，1行程で酸化水の污れ が増して行くにもかかわらず酸化水の細菌污染恃泪め られなかった，清拭前後の細菌数は, 泊拭前に比べ て，1/2 から 1/15 以下の減少が見られた.

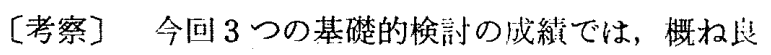
好であった。今後，院内感染子防を含めた多方面での 用途に期待出来ると思われる。 